\title{
Perbandingan Kebutuhan Propofol dan Lama Bangun antara Kombinasi Propofol-Ketamin dan Propofol-Fentanil pada Pasien yang Dilakukan Kuretase yang Diukur dengan Bispectral Index (BIS)
}

\author{
Wirawan Anggorotomo, ${ }^{1}$ Rudi K. Kadarsah, ${ }^{2}$ Ezra Oktaliansah ${ }^{2}$ \\ ${ }^{1}$ SMF Anestesiologi Rumah Sakit Umum Dr. Abdul Moeloek Bandar Lampung, \\ ${ }^{2}$ Departemen Anestesiologi dan Terapi Intensif \\ Fakultas Kedokteran Universitas Padjadjaran/Rumah Sakit Dr. Hasan Sadikin Bandung
}

\begin{abstract}
Abstrak
Pemberian sedasi dan analgesi yang efektif, efisien, aman, mudah didapat, dan juga murah diperlukan untuk mengurangi nyeri serta kecemasan selama kuretase. Tujuan penelitian ini adalah mengetahui perbedaan kebutuhan propofol dan lama bangun antara propofol-ketamin dan propofol-fentanil pada pasien yang dilakukan kuretase. Dilakukan penelitian uji klinis acak tersamar tunggal pada 60 pasien yang menjalani kuretase di Rumah Sakit Dr. Hasan Sadikin Bandung periode September-November 2014. Pasien dibagi dalam dua kelompok, yaitu propofol-ketamin (PK) dan propofol-fentanil (PF). Data hasil penelitian untuk tekanan darah, laju nadi, laju napas, saturasi oksigen, dan skor bispectral index (BIS) dianalisis dengan uji-t dan Uji Mann-Whitney. Hasil penelitian menunjukkan kebutuhan propofol berbeda secara sangat bermakna ( $\mathrm{p}<0,001$ ), pada kelompok PK terdapat 4/30 subjek yang mendapatkan tambahan propofol, sedangkan pada kelompok PF sebanyak 14/30 subjek. Lama bangun pada kelompok PK adalah 25,75 $\pm 2,47$ menit, sedangkan pada kelompok PF adalah 21,08 $\pm 2,52$. Secara statistik hasil tersebut berbeda secara sangat bermakna $(\mathrm{p}<0,001)$. Simpulan, kebutuhan propofol pada kelompok PK lebih sedikit dibanding dengan kelompok PF dan lama bangun pada kelompok PK lebih lama dibanding dengan kelompok PF.
\end{abstract}

Kata kunci: Bispectral index, kebutuhan propofol, kuretase, lama bangun

\section{Comparison of Propofol Requirements and Emergence Time between Propofol-Ketamine and Propofol-Fentanyl Combinations in Patients Undergoing Curretage using Bispectral Index (BIS) Monitoring}

\begin{abstract}
Adequate administration of safe, easy-to-obtain, and constantly available sedatives and analgesia, is needed for pain reduction throughout curettage procedures. The goal of this study was to examine differences in propofol requirements and emergence time between propofol-ketamine and propofolfentanyl combinations in patients undergoing curettage. A single-blind randomized controlled trial study was performed on 60 patients who underwent curettage procedures. The patients were divided into two groups: propofol-ketamine (PK) and propofol-fentanyl (PF). Blood pressure, pulse rate, respiration rate, and oxygen saturation and BIS data were analysed using a t-test and Mann-Whitney test. This study showed that propofol requirements differ significantly $(\mathrm{p}<0.001)$ between the two groups where in PK group where $4 / 30$ subjects received additional propofol, compared to PF group 14/30 subjects received additional propofol. The wake up time for PK group was $25.75 \pm 2.47$ minutes compared to $21.08 \pm 2.52$ minutes for the $\mathrm{PF}$ group. The difference was statistically significant $(\mathrm{p}<0.001)$. The conclusions of this study are propofol requirements for PK group is less compared to PF group and the emergence time for PK group is longer compared to PF group.
\end{abstract}

Key words: Bispectral index, curettage, emergence time, propofol requirements

Korespondensi: Wirawan Anggorotomo, dr., SpAn, SMF Anestesiologi Rumah Sakit Umum Dr. Abdul Moeloek Bandar Lampung, Jl. Dr. Rivai No.6, Kota Bandar Lampung, Tlp 0721703312, Mobile 081272242434, Email senandung.bius@ gmail.com 


\section{Pendahuluan}

Kuretase merupakan cara untuk mengeluarkan sisa-sisa jaringan abortus dengan cepat dalam waktu 5-15 menit, meskipun pada beberapa kasus memerlukan waktu yang lebih lama. Umumnya kondisi pasien memenuhi syarat sebagai pasien rawat jalan, yaitu pasien dalam keadaan sehat, waktu tindakan singkat, tidak memerlukan pelemas otot, tidak menimbulkan perubahan fisiologis tubuh, serta kemungkinan perdarahan dan komplikasi pascabedah yang minimal. ${ }^{1,2}$ Untuk melakukan kuretase dengan baik diperlukan tindakan anestesia. Tindakan anestesia tersebut memerlukan obat-obatan anestesi yang memiliki efek sedasi dan analgesi yang cukup kuat, mula kerja cepat, masa kerja singkat, waktu pulih cepat, dapat menurunkan kesadaran dengan cepat dan juga aman, tidak menyebabkan perubahan kardiovaskular dan pernapasan, memiliki efek amnesia, dan juga tidak menimbulkan efek samping., ${ }^{2,3}$

Prosedur sedasi adalah teknik pemberian sedatif ataupun obat disosiatif dengan atau tanpa pemberian analgetik untuk mencapai keadaan yang memungkinkan pasien dapat menerima proseduryang tidak menyenangkan, dengan tetap menjaga fungsi kardiovaskular dan juga respirasi. Prosedur sedasi bertujuan menurunkan kesadaran dengan tetap menjaga kemampuan pasien untuk mempertahankan oksigenasi serta mengendalikan jalan napas sendiri. Selain itu, sedasi dapat memberikan efek analgesia, amnesia, dan juga mengurangi kecemasan selama prosedur. Bispectral index (BIS) merupakan suatu metode objektif untuk mengukur kedalaman sedasi. ${ }^{4}$

Bispectral index (BIS) memberikan prediksi terbaik terhadap derajat kesadaran pada saat pasien teranestesi. Bispectral index (BIS) dapat mendeteksi perubahan yang terjadi pada gelombang-gelombang di dalam otak seperti pada electroencephalogram (EEG), terutama menilai gelombang $\beta$ dan mengonversikannya menjadi angka. Angka tersebut mempunyai rentang antara 100 sampai 0 (nol) dengan nilai 100 berarti pasien sadar penuh serta 0 berarti tidak didapatkan aktivitas gelombang otak (mati otak). ${ }^{5}$
Propofol adalah obat anestesia intravena golongan hipnotik-sedatif, nonopioid, dan nonbarbiturat dengan mula kerja cepat dan lama kerja yang singkat. Propofol mempunyai sifat antiemetik serta amnesia, namun sangat sedikit sifat analgesi. Efek sampingnya adalah depresi napas, gangguan kognitif sementara, dan nyeri pada tempat penyuntikan. Karena sifat analgesinya yang sedikit, propofol sering dikombinasikan dengan obat analgesia lain.,6

Ketamin merupakan obat yang populer untuk prosedur sedasi analgesi karena tidak mendepresi sirkulasi serta respirasi, memiliki rentang keamanan yang tinggi, sederhana cara penggunaannya, dan juga murah, namun ketamin mempunyai potensi efek samping seperti halusinasi yang tidak menyenangkan, hipersalivasi, peningkatan tekananintrakranial dan juga intraokuler, serta waktu pulih yang relatif lama. Ketamin tidak dapat diberikan pada pasien dengan hipertensi, peningkatan tekanan intrakranial, penyakit neuropsikiatri, dan penyerta lain seperti kejang atau psikosis. Efek samping ketamin dapat dikurangi dengan cara mengombinasikannya dengan obat lain, seperti propofol ataupun midazolam sehingga mengurangi dosis ketamin yang digunakan.,

Fentanil memiliki efek analgetik dan dapat memberikan efek sedasi pada penggunaan dosis besar sehingga harus dikombinasikan dengan obat sedasi lain. Efek samping fentanil adalah depresi napas dengan tingkat depresi pernapasan berhubungan dengan besar dosis yang diberikan. Efek samping lainnya adalah bradikardia, hipotensi, mual, muntah, dan juga pusing. ${ }^{6,9}$

Sebuah penelitian yang membandingkan kombinasi antara propofol-ketamin dan propofol-fentanil terhadap prosedur sedasi pada pasien obesitasyang menjalani endoscopic retrograde cholangiopancreatography (ERCP) menyimpulkan bahwa dosis propofol yang diperlukan untuk mendapatkan tingkat sedasi dalam pada kelompok propofol-ketamin lebih sedikit dibanding dengan propofol-fentanil. Penelitian lainnya menyatakan bahwa kejadian hipotensi, bradikardia, apnea, dan desaturasi lebih sedikit pada kelompok propofol-ketamin. Hal ini disebabkan oleh kombinasi propofol 
dan ketamin bersifat antagonis terhadap efek samping obat masing-masing, namun waktu pemulihan pada kelompok propofol-ketamin lebih panjang bila dibanding dengan kelompok propofol-fentanil. ${ }^{10,11}$

Penelitian lain membandingkan kombinasi antara propofol-ketamin dan propofol-fentanil pada tindakan kolonoskopi yang menunjukkan bahwa pada kedua kelompok dicapai sedasi tingkat sedang (moderate) dan tidak terjadi efek samping. Kombinasi propofol-ketamin lebih menguntungkan karena pemberian dosis rendah keduanya dapat menurunkan kejadian efek samping obat, namun di sisi lain ketamin dapat menyebabkan reaksi psikomimetik tidak diharapkan yang dikenal dengan "emergence reactions", yang terjadi saat bangun setelah anestesi. ${ }^{12}$

Tujuan pada penelitian ini membandingkan kebutuhan propofol dan lama bangun antara kombinasi propofol-ketamin dan propofolfentanil pada pasien yang dilakukan kuretase.

\section{Subjek dan Metode}

Penelitian ini merupakan penelitian uji klinis eksperimental dengan metode acak tersamar tunggal dilakukan terhadap 60 pasien yang menjalani tindakan kuretase. Penelitian ini dilakukan di dalam ruang bersalin Departemen Obstetri dan Ginekologi Rumah Sakit Dr. Hasan Sadikin (RSHS) Bandung periode SeptemberNovember 2014.

Kriteria inklusi adalah pasien abortus yang akan menjalani kuretase dengan puasa preoperatif yang cukup, status fisik menurut American Society of Anesthesiologists (ASA) skala I dan II, dan usia 18-40 tahun. Kriteria eksklusi adalah riwayat alergi terhadap obatobat penelitian, indeks massa tubuh (body mass index/BMI) $>30 \mathrm{~kg} / \mathrm{m}^{2}$, dan hipertensi. Kriteria pengeluaran bila terjadi perdarahan hebat sebelum kuretase dan tindakan kuretase dilanjutkan dengan tindakan medik lain. Besar sampel ditentukan menggunakan rumus untuk menguji perbedaan dua rata-rata, didapatkan jumlah sampel minimal adalah 56 dan pada penelitian ini melibatkan 60 sampel.

Setelah mendapat persetujuan dari Komite
Etik Penelitian Kesehatan Fakultas Kedokteran Unpad/Rumah Sakit Dr. Hasan Sadikin (RSHS) Bandung, lalu diberikan penjelasan mengenai tujuan, kegunaan, dan juga tata cara penelitian kepada subjek penelitian. Persetujuan subjek penelitian diperoleh dengan menandatangani surat persetujuan (informed consent). Subjek dibagi menjadi dua kelompok, yaitu kelompok propofol-ketamin (PK) dan propofol-fentanil (PF). Sebelum diposisikan telentang, dilakukan pengukuran tinggi serta berat badan subjek penelitian terlebih dahulu, kemudian pada kedua kelompok dilakukan pemasangan akses intravena dan diberikan cairan Ringer laktat (RL). Monitor life window L 6.000 dipasang pada tubuh subjek penelitian dan alat monitor bispectral index (BIS) dipasang di dahi, pelipis kiri, dan daerah depan telinga kiri. Kondisi awal kesadaran, tekanan darah, laju nadi, laju napas, saturasi oksigen, skor BIS, usia, berat badan, dan tinggi badan subjek dicatat sebagai data dasar. Sebelum obat dimasukkan, pasien diposisikan litotomi.

Pada kelompok PK diberikan bolus ketamin 0,5 mg/kgBB pada menit ke-2,5 kemudian propofol $1 \mathrm{mg} / \mathrm{kgBB}$ secara perlahan pada saat menit ke-5 hingga skor BIS 60-90, lalu tindakan kuretase dimulai pada menit ke-7,5. Apabila selama kuretase skor BIS >90 maka diberikan tambahan propofol $0,5 \mathrm{mg} / \mathrm{kgBB}$ hingga skor BIS 60-90. Apabila skor BIS <90, namun terjadi peningkatan dari tekanan darah dan juga laju nadi $>15 \%$ dari nilai dasar maka diberikan tambahan ketamin 0,25 mg/kgBB. Apabila saat dilakukan kuretase skor BIS $>90$ disertai peningkatan tekanan darah dan laju nadi $>15 \%$ dari nilai dasar maka diberikan tambahan propofol dan ketamin dengan dosis setengah dosis awal.

Pada kelompok PF diberikan bolus fentanil $1 \mu \mathrm{g} / \mathrm{kgBB}$ pada menit yang ke-2,5, kemudian propofol $1 \mathrm{mg} / \mathrm{kgBB}$ secara perlahan pada menit yang ke-5 hingga skor BIS 60-90, lalu tindakan kuretase dimulai pada menit ke-7,5. Apabila selama kuretase skor BIS $>90$, maka diberikan tambahan propofol $0,5 \mathrm{mg} / \mathrm{kgBB}$ hingga skor BIS 60-90. Apabila skor BIS <90, namun terjadi peningkatan tekanan darah dan laju nadi $>15 \%$ dari nilai dasar maka diberikan 
Tabel 1 Skor Bispectral Index (BIS) dan Derajat Sedasi

\begin{tabular}{cl}
\hline Nilai BIS & \multicolumn{1}{c}{ Derajat Sedasi } \\
\hline $95-100$ & Sadar penuh \\
$90-95$ & $\begin{array}{l}\text { Sedasi ringan, berespons } \\
\text { terhadap rangsang verbal biasa }\end{array}$ \\
$60-90$ & $\begin{array}{l}\text { Sedasi dalam, berespons terhadap } \\
\text { rangsang verbal yang keras atau } \\
\text { rangsang somatik }\end{array}$ \\
$40-60$ & $\begin{array}{l}\text { Anestesi umum, tidak berespons } \\
\text { terhadap rangsang verbal }\end{array}$ \\
$20-40$ & $\begin{array}{l}\text { Hipnosis dalam } \\
\text { Burst suppression }\end{array}$ \\
0 & Mati otak \\
\hline
\end{tabular}

Dikutip dari: Seatt dan Kelley ${ }^{5}$

tambahan fentanil $0,5 \mu \mathrm{g} / \mathrm{kgBB}$. Apabila skor BIS >90 diikuti dengan peningkatan tekanan darah dan laju nadi $>15 \%$ dari nilai dasar maka diberikan tambahan propofol serta fentanil dengan dosis setengah dosis awal. Pemberian propofol ataupun ketamin/fentanil tambahan dapat diulang setelah 1 menit bila diperlukan dan dicatat jumlah serta waktu pemberiannya.

Pengukuran terhadap tekanan darah, laju nadi, laju napas, saturasi oksigen, dan skor BIS dilakukan sebelum pemberian obat, tiap 2,5 menit selama tindakan, dan setelah tindakan kuretase hingga skor BIS 100. Bila terjadi desaturasi $\left(\mathrm{SpO}_{2}<90 \%\right)$ ataupun henti napas selama $\geq 15$ detik, dilakukan bantuan jalan napas dan atau ventilasi sesuai kebutuhan. Bila terjadi hipotensi (tekanan arteri ratarata menurun $>20 \%$ dari nilai dasar) maka diberikan cairan kristaloid 5-10 mL/kgBB dan bila tidak berespons maka diberikan efedrin $\mathrm{HCl} 5 \mathrm{mg}$ intravena. Bila terjadi bradikardia (laju nadi $<50 \mathrm{x} /$ menit) diberikan atropin 20 $\mu \mathrm{g} / \mathrm{kg}$ intravena. Mual dan muntah dicegah dengan pemberian ondansetron $0,1 \mathrm{mg} / \mathrm{kgBB}$. Kejadian efek samping lain seperti halusinasi, agitasi, pusing, maupun nyeri dicatat serta dilakukan penanganan sesuai kebutuhan.

Ujistatistikayang digunakan pada penelitian ini adalah uji-t untuk membandingkan data yang tidak berpasangan; uji chi-kuadrat untuk data kategori; dan Uji Mann-Whitney untuk membandingkan data-data tidak terdistribusi normal. Hasil uji statistika dianggap bermakna bila nilai $\mathrm{p}<0,05$. Perhitungan dan analisis data menggunakan statistical product and service solution (SPSS) 13.0 for Windows.

\section{Hasil}

Penelitian ini dilakukan terhadap 60 subjek penelitian yang menjalani kuretase di ruang bersalin Rumah Sakit Dr. Hasan Sadikin (RSHS) Bandung. Perbandingan variabel usia, berat badan, tinggi badan, indeks massa tubuh, dan

Tabel 2 Karakteristik Umum Subjek Penelitian

\begin{tabular}{|c|c|c|c|c|c|}
\hline \multirow{3}{*}{ Karakteristik } & \multicolumn{4}{|c|}{ Kelompok } & \multirow{3}{*}{ Nilai $p$} \\
\hline & \multicolumn{2}{|c|}{ Propofol-Ketamin } & \multicolumn{2}{|c|}{ Propofol-Fentanil } & \\
\hline & Rata-rata & SD & Rata-rata & SD & \\
\hline Usia (tahun) & 29,97 & 6,64 & 30,10 & 6,76 & 0,882 \\
\hline Berat badan (kg) & 59,5 & 5,54 & 58,2 & 6,12 & 0,152 \\
\hline Tinggi badan $(\mathrm{cm})$ & 155,6 & 0,04 & 155,8 & 0,05 & 0,894 \\
\hline BMI $\left(\mathrm{kg} / \mathrm{m}^{2}\right)$ & 24,85 & 2,07 & 23,15 & 2,18 & 0,948 \\
\hline \multicolumn{6}{|l|}{ Lama tindakan (menit) } \\
\hline Abortus inkomplet & 7,4 & 0,22 & 9,25 & 1,91 & 0,074 \\
\hline Abortus insipiens & 9,3 & 0,68 & 11,7 & 2,42 & 0,062 \\
\hline Blighted ovum & 11,0 & 1,00 & 11,5 & 0,70 & 0,800 \\
\hline
\end{tabular}

Keterangan: data ditampilkan dalam nilai rata-rata dan standar deviasi (SD). Uji statistika menggunakan Uji MannWhitney dan uji-t. Hasil bermakna bila nilai $\mathrm{p}<0,05$ 
Tabel 3 Karakteristik Tekanan DarahSistol, Tekanan Darah Diastol, Tekanan Arteri Rata-rata, Laju Nadi, Laju Napas, Saturasi Oksigen dan Skor Bispectral Index Subjek Penelitian Sebelum Perlakuan

\begin{tabular}{lccccc}
\hline \multirow{2}{*}{ Karakteristik } & \multicolumn{5}{c}{ Kelompok } \\
\cline { 2 - 5 } & \multicolumn{2}{c}{ Propofol-Ketamin } & \multicolumn{2}{c}{ Propofol-Fentanil } & Nilai p \\
\hline & Rata-rata & SD & Rata-rata & SD \\
\hline Tekanan darah sistol (mmHg) & 119,27 & 8,21 & 123,17 & 7,27 & 0,056 \\
Tekanan darah diastol (mmHg) & 72,27 & 8,14 & 74,60 & 8,62 & 0,285 \\
Tekanan arteri rata-rata (mmHg) & 88,33 & 7,57 & 90,27 & 8,54 & 0,114 \\
Laju nadi (x/menit) & 83,21 & 8,71 & 80,36 & 7,33 & 0,372 \\
Laju napas (x/menit) & 19,55 & 1,78 & 19,64 & 2,29 & 0,089 \\
Saturasi oksigen (\%) & 99,64 & 0,69 & 99,51 & 0,73 & 0,221 \\
Skor bispectral index & 100,00 & 0,00 & 100,00 & 0,00 & 1,000 \\
\hline
\end{tabular}

Keterangan: data ditampilkan dalam nilai rata-rata dan standar deviasi (SD). Uji statistik menggunakan Uji Mann-Whitney dan uji-t. Hasil bermakna bila nilai $\mathrm{p}<0,05$

lama tindakan pada kedua kelompok secara statistika tidak berbeda bermakna ( $p>0,05$; Tabel 2).

Variabel tekanan darah sistol, tekanan darah diastol, tekanan arteri rata-rata, laju nadi, laju napas, saturasi oksigen, serta skor bispectral index pada kedua kelompok perlakuan juga tidak berbeda bermakna ( $p>0,05$; Tabel 3).

Skor bispectral index (BIS) pada kelompok PK lebih rendah dibanding dengan kelompok PF pada sebagian besar waktu pengukuran dengan perbedaan sangat bermakna $(\mathrm{p}<0,01$;

Tabel 4 Perbandingan Skor Bispectral Index antara Kedua Kelompok

\begin{tabular}{|c|c|c|c|c|c|}
\hline \multirow{3}{*}{ Skor Bispectral Index } & \multicolumn{4}{|c|}{ Kelompok } & \multirow{3}{*}{ Nilai p } \\
\hline & \multicolumn{2}{|c|}{ Propofol-Ketamin } & \multicolumn{2}{|c|}{ Propofol-Fentanil } & \\
\hline & Rata-rata & SD & Rata-rata & SD & \\
\hline to & 100,00 & 0,00 & 100,00 & 0,00 & 1,000 \\
\hline $\mathrm{t} 1$ & 98,73 & 1,86 & 96,93 & 1,55 & 0,000 \\
\hline $\mathrm{t} 2$ & 68,10 & 7,38 & 78,80 & 5,22 & 0,000 \\
\hline $\mathrm{t} 3$ & 70,83 & 9,96 & 79,90 & 6,83 & 0,000 \\
\hline $\mathrm{t} 4$ & 71,60 & 10,53 & 77,60 & 6,73 & 0,000 \\
\hline $\mathrm{t} 5$ & 72,60 & 7,75 & 80,67 & 5,10 & 0,000 \\
\hline t6 & 73,50 & 5,28 & 80,23 & 4,35 & 0,000 \\
\hline $\mathrm{t} 7$ & 77,20 & 5,73 & 88,77 & 4,53 & 0,000 \\
\hline t8 & 80,20 & 5,87 & 91,13 & 4,15 & 0,000 \\
\hline t9 & 83,63 & 5,44 & 94,87 & 3,76 & 0,000 \\
\hline $\mathrm{t} 10$ & 87,03 & 5,13 & 96,64 & 3,77 & 0,000 \\
\hline $\mathrm{t} 11$ & 89,70 & 4,32 & 98,07 & 2,69 & 0,000 \\
\hline $\mathrm{t} 12$ & 92,40 & 3,52 & 98,86 & 2,04 & 0,000 \\
\hline
\end{tabular}

Keterangan: data ditampilkan dalam nilai rata-rata dan SD. Nilai p dihitung berdasarkan Uji Mann-Whitney (data tidak normal) dan uji-t (data normal). Waktu (t) diukur tiap 2,5 menit. Hasil bermakna bila nilai p<0,05 dan sangat bermakna bila nilai $\mathrm{p}<0,01$ 
Tabel 5 Perbandingan Jumlah Subjek yang Mendapatkan Tambahan Propofol dengan Ketamin/Fentanil antara Kedua Kelompok

\begin{tabular}{lccc}
\hline \multirow{2}{*}{ Obat tambahan } & \multicolumn{2}{c}{ Kelompok } & \\
\cline { 2 - 3 } & $\begin{array}{c}\text { Propofol-Ketamin } \\
(\mathbf{n = 3 0 )}\end{array}$ & $\begin{array}{c}\text { Propofol-Fentanil } \\
(\mathbf{n = 3 0 )}\end{array}$ & \multirow{2}{*}{ Nilai $\mathbf{p}$} \\
\cline { 2 - 3 } & $\mathbf{n}$ & $\mathbf{n}$ & 0,005 \\
\hline Propofol & 4 & 14 & 1,000 \\
\hline Ketamin/fentanil & 1 & 1 & \\
\hline
\end{tabular}

Keterangan: data ditampilkan dalam nilai rata-rata dan SD. Nilai p dihitung berdasarkan Uji Mann-Whitney (data tidak normal) dan uji-t (data normal). Hasil bermakna bila nilai $\mathrm{p}<0,05$, dan sangat bermakna bila nilai $\mathrm{p}<0,01$

Tabel 4), namun secara klinis hasil tersebut tidak berbeda bermakna karena berada dalam interval sedasi yang sama (skor BIS 60-90).

Pada kelompok PK didapatkan 4 dari 30 orang subjek penelitian yang mendapatkan tambahan propofol dengan dosis rata-rata 27,75 mg. Pada kelompok PF sebanyak 14 dari 30 subjek yang mendapatkan tambahan propofol dengan dosis rata-rata 27,39 mg. Hasil Uji Mann-Whitney menunjukkan bahwa subjek yang mendapatkan tambahan propofol antara kedua kelompok perlakuan berbeda bermakna ( $\mathrm{p}=0,005$; Tabel 5).

Pada tiap kelompok perlakuan terdapat 1 dari 30 subjek yang mendapatkan tambahan propofol dan juga ketamin/fentanil. Hasil uji statistika menyimpulkan bahwa perbedaan jumlah subjek yang mendapatkan tambahan propofol dengan ketamin/fentanil antara kedua kelompok perlakuan tidak bermakna $(\mathrm{p}=1,000$; Tabel 5).

Lama bangun pada kelompok PK adalah $25,75 \pm 2,47$ menit, sedangkan pada kelompok PF adalah 21,08 $\pm 2,52$ menit. Hasil perhitungan uji-t menunjukkan bahwa lama bangun antara kedua kelompok perlakuan tersebut berbeda sangat bermakna ( $\mathrm{p}=0,001$; Tabel 6).

Temuan lain berupa efek samping yang terjadi pada kelompok PK berupa pusing pada 7 dari 30 orang, mual 3 dari 30 orang, dan halusinasi seorang dari 30 orang, sedangkan pada kelompok PF yang mengalami pusing sebanyak 10 dari 30 orang serta mual 5 dari 30 orang. Secara klinis jumlah subjek penelitian yang mengalami keluhan pada kelompok PK lebih sedikit dibanding dengan kelompok PF.

\section{Pembahasan}

Data-data karakteristik umum menunjukkan bahwa tidak tidak terdapat perbedaan yang bermakna $(p>0,05)$ terhadap variabel usia, berat badan, tinggi badan, indeks massa tubuh (IMT), lama tindakan, hemodinamik, dan skor bispectral index (BIS) antara kedua kelompok perlakuan. Hal tersebut menunjukkan bahwa sampel yang diambil untuk penelitian ini relatif homogen sehingga layak diperbandingkan.

Kebutuhan untuk tindakan anestesi di luar ruangan operasi saat ini semakin meningkat, salah satunya adalah prosedur sedasi dan juga analgesi pada pasien yang menjalani kuretase.

Tabel 6 Perbandingan Dosis Propofol dan Lama Bangun antara Kedua Kelompok

\begin{tabular}{|c|c|c|c|c|c|}
\hline \multirow{3}{*}{ Variabel } & \multicolumn{4}{|c|}{ Kelompok } & \multirow{3}{*}{ Nilai $\mathbf{p}$} \\
\hline & \multicolumn{2}{|c|}{ Propofol-Ketamin $(n=30)$} & \multicolumn{2}{|c|}{ Propofol-Fentanil $(n=30)$} & \\
\hline & Rata-rata & SD & Rata-rata & SD & \\
\hline Dosis propofol (mg) & 27,75 & 2,06 & 27,39 & 2,57 & 0,572 \\
\hline Lama bangun (menit) & 25,75 & 2,47 & 21.08 & 2,52 & 0,001 \\
\hline
\end{tabular}

Keterangan: data ditampilkan dalam nilai rata-rata dan SD. Nilai p dihitung berdasarkan Uji Mann-Whitney. Hasil bermakna bila nilai $\mathrm{p}<0,05$ dan sangat bermakna bila nilai $\mathrm{p}<0,01(* *)$. 
Tujuan pemberian sedasi dalam adalah untuk memfasilitasi prosedur dengan mengurangi nyeri dan kecemasan, memberi efek amnesia, mengurangi potensi terjadi efek samping obat, mengontrol perilaku, serta mempertahankan status kardiovaskular dan juga respirasi yang stabil. $^{13,14}$

Penilaian derajat sedasi merupakan bagian yang terpadu dari prosedur sedasi karena kedalaman sedasi yang ingin dicapai sesuai dengan prosedur yang dilakukan. Kedalaman anestesi atau sedasi dapat dinilai memakai metode subjektif maupun objektif. Bispectral index merupakan salah satu metode penilaian objektif untuk kedalaman anestesi maupun sedasi. ${ }^{4}$

Propofol merupakan obat sedasi yang paling banyak dipergunakan pada prosedur sedasi dan analgesi. Propofol memiliki profil farmakokinetik dan juga farmakodinamik yang superior dengan waktu induksi anestesi yang cepat untuk mencapai sedasi yang dalam dengan durasi kerja singkat. Namun, propofol dapat menyebabkan depresi pernapasan dan hipotensi. Propofol memberikan efek amnesia yang poten, namun sedikit efek analgesi. Oleh karena itu, opioid dengan kerja cepat seperti fentanil (dosis 1-2 $\mu \mathrm{g} / \mathrm{kgBB}$ ) sering digunakan sebagai analgesi, namun fentanil juga memiliki efek depresi pernapasan seperti pada propofol sehingga dapat bersifat aditif bila digunakan bersamaan..$^{15}$

Ketamin dapat menurunkan skor nyeri dan mengurangi kebutuhan analgetik pascabedah sebesar 35-40\%. Kekurangan ketamin adalah efek kardiotoksik, episode psikotik, dan waktu pulih yang memanjang. Pemberian kombinasi ketamin dengan beberapa obat sedasi seperti benzodiazepin dan juga propofol telah banyak digunakan untuk mengurangi efek samping. Kombinasi propofol dengan ketamin banyak digunakan pada pembedahan arteri koroner dewasa, radiologi intervensi, dan sedasi pada biopsi endometrium. ${ }^{3}$

Pemberian propofol dosis $1 \mathrm{mg} / \mathrm{kgBB}$ pada kelompok PK dan juga PF, secara statistika menunjukkan perbedaan hasil yang sangat bermakna, tetapi secara klinis, pemberian propofol memberikan efek sedasi pada kedua kelompok dengan nilai BIS berada dalam interval sedasi (60-90).

Hasil penelitian ini menunjukkan bahwa pada kelompok PK terdapat 4 dari 30 orang subjek yang mendapatkan tambahan propofol dengan dosis rata-rata $27,75 \mathrm{mg}$, sedangkan pada kelompok PF terdapat sebanyak 14 dari 30 orang dengan dosis rata-rata $27,39 \mathrm{mg}$. Hasil tersebut sesuai dengan penelitian Khajavi dkk. ${ }^{12}$ yang menyatakan bahwa penggunaan kombinasi ketamin dan propofol untuk sedasi lebih menguntungkan karena mengurangi dosis obat masing-masing sehingga risiko efek samping lebih sedikit, namun efek sedasi yang diinginkan tercapai. Pada penelitian tersebut dijelaskan bahwa kadar ketamin yang rendah dalam plasma dapat menghambat sensitisasi nosiseptif pusat dan memiliki efek analgesia pre-emtif.

Yuce $\mathrm{dkk}^{3}$ pada penelitiannya menyatakan bahwa ketamin memiliki efek analgesi pada dosis subdisosiatif. Pemberian ketamin dapat mengurangi kebutuhan propofol sehingga kondisi hemodinamik menjadi lebih stabil. Efek sedasi serta antiemetik propofol diduga dapat mengatasi efek mual, muntah, dan juga psikomimetik akibat dari pemberian ketamin. Kombinasi ketamin dan propofol digunakan juga untuk prosedur sedasi dan analgesi pada pasien pediatrik. Ketamin dapat mengurangi risiko depresi napas dan kebutuhan pemberian obat ulangan. ${ }^{6}$

Jumlah subjekpenelitian yang mendapatkan tambahan propofol dan ketamin/fentanil pada tiap kelompok hanya seorang dari 30 subjek. Hasil ini sesuai dengan penelitian sebelumnya yang menyatakan bahwa pemberian analgesi tambahan selama prosedur sedasi memakai propofol tidaklah rutin dilakukan. Pemberian propofol telah direkomendasikan sebagai obat tunggal setelah tercapainya analgesi adekuat dengan opioid. Nyeri prasedasi tidak selalu menggambarkan kekuatan analgesi selama prosedur. Meskipun pada pasien yang tersedasi tidak menunjukkan respons terhadap nyeri secara jelas, namun rangsang nyeri dapat mensensitisasi saraf yang dapat menyebabkan peningkatan nyeri pascatindakan dan juga hiperalgesia. Pemberian analgesi intravena, 
seperti opioid dan ketamin disarankan untuk mencegah kejadian ini. ${ }^{15}$

Pada penelitian ini didapatkan bahwa lama bangun pada kelompok PK adalah 25,75 $\pm 2,47$ menit, sedangkan pada kelompok PF adalah $21,08 \pm 2,52$. Hasil ini sesuai dengan penelitian sebelumnya yang menyatakan bahwa waktu bangun pada kombinasi propofol dan ketamin lebih lama dibanding dengan propofol-fentanil. Klirens ketamin yang lebih lambat dibanding dengan fentanil diduga menjadi penyebab hal ini. ${ }^{10}$

Temuan lain adalah kejadian efek samping pada subjek penelitian. Pada kelompok PK, keluhan pusing didapatkan pada $7 / 30$ subjek, mual $3 / 30$ subjek, serta halusinasi $1 / 30$ subjek (3\%), sedangkan pada kelompok PF, keluhan pusing didapatkan sebanyak 10/30 subjek dan mual 5/30 subjek. Hasil ini bermakna secara klinis, namun diperlukan sampel yang lebih banyak untuk dapat menilai kemaknaan secara statistika.

Pada hasil penelitian ini didapatkan waktu bangun yang lebih lama pada kelompok $\mathrm{PK}$, namun efek samping yang terjadi lebih sedikit bila dibanding dengan kelompok PF. Hal tersebut disebabkan kombinasi propofol dan ketamin mengurangi dosis obat masingmasing sehingga efek samping pun menurun. Efek samping akibat pemberian propofol dosis tinggi seperti depresi napas serta gangguan hemodinamik akan berkurang bila diberikan bersama ketamin. ${ }^{14,16}$

Akin dkk. ${ }^{14}$ menyatakan kejadian depresi napas lebih banyak terjadi pada kelompok propofol dan ketamin, namun tidak ditemukan perbedaan bermakna pada tanda-tanda vital. Efek samping takikardia maupun hipertensi tidak ditemukan, hal tersebut kemungkinan disebabkan oleh suatu efek simpatomimetik ketamin yang dapat diatasi oleh propofol. Tidak terdapat perbedaan waktu pemulihan antara kedua kelompok penelitian, sedangkan waktu pemulangan pasien lebih lama pada kelompok propofol dan ketamin. Hal ini disebabkan oleh kejadian vertigo, mual, muntah, dan gangguan penglihatan yang lebih tinggi pada kelompok tersebut.

\section{Simpulan}

Pemberian kombinasi propofol $1 \mathrm{mg} / \mathrm{kgBB}$ dan ketamin 0,5 mg/kgBB membutuhkan propofol tambahan yang lebih sedikit dan waktu bangun yang lebih lama dibanding dengan kombinasi propofol $1 \mathrm{mg} / \mathrm{kgBB}$ dan fentanil $1 \mu \mathrm{g} / \mathrm{kgBB}$ pada pasien yang dilakukan kuretase dengan sedasi dan analgesi.

\section{Daftar Pustaka}

1. Budi H, Firman FW, Johanes CM. Abortus berulang. Edisi ke-1. Bandung: Refika Aditama; 2009.

2. Calvache JA, Delgado-Noguera M, Lessaffte E, Stolker RJ. Anaesthesia for evacuation of incomplete miscarriage. Cochrane Database Systematic Rev. 2012;4:2-14.

3. Yuce HH, Ahmet K, Nuray A, Tekin B, Karahan M, Buyukfirat E. Propofolketamine combination has favorable impact on orientation times and pain scores compared to propofol in dilatation and curretage: a randomized trial. Acta Med Medit. 2013;29:539-43.

4. Miner JR, Krauss B. Procedural sedation and analgesia research: state of the art. Acad Emerg Med. 2007;14:170-8.

5. Scott D, Kelley MD. Monitoring consciousness using the bispectral index during anesthesia, a pocket guide for clinicians. Edisi ke-2. Mansfield: Covidien; 2010.

6. Arora SM. Combining ketamine and propofol ("ketofol") for emergency department procedural sedation and analgesia: a review. West J Emerg Med. 2008;9(1):20-3.

7. Nejati A, Shariat R, Ashraf H, Labaf A, Golshani K. Ketamine/propofol versus midazolam/fentanyl for procedural sedation and analgesia in the emergency department: a randomized, prospective, double-blind trial. Acad Emerg Med. 2011;18:800-6.

8. Morgan G, Mikhail M, Murray M. Clinical anesthesiology. Edisi ke-5. Appleton and Lange: McGraw-Hill Company; 2013.

9. White PF. Opioids. Dalam: Barash PG, Cullen BF, Stoelting RK, penyunting. Clinical anesthesia. Edisi ke-7. Philadelphia: 
Lippincott, Williams and Wilkins; 2009. hlm. 501-22.

10. Hasanein R,El-SayedW.Ketamine/propofol versus fentanyl/propofol for sedating obese patients undergoing endoscopic retrograde cholangiopancreatography (ERCP). EgJA. 2013;29:207-11.

11. Khutia SK, Mohan M, Das S, Basu SR. Intravenous infusion of ketamine-propofol can be an alternative to intravenous infusion of fentanyl-propofol for deep sedation and analgesia in paediatric patients undergoing emergency short surgical procedures. Indian J Anaesth. 2012;56:145-50.

12. Khajavi M, Emami A, Etezadi F, Safari S, Sharifi A, Moharari S. Conscious sedation and analgesia in colonoscopy: ketamine/ propofol combination has superior patient satisfaction versus fentanyl/propofol. Anesth Pain. 2013;3(1):208-13.

13. Akin A, Esmaoglu A, Tosun Z. Comparison of propofol with propofol-ketamine combination in pediatric patients undergoing auditory brainstem response testing. Int J Otorhinolaryngol.
2005;69:1541-5.

14. Akin A, Guler G, Esmaoglu A, Bedirli N. A comparison of fentanyl-propofol with a ketamine-propofol combination for sedation during endometrial biopsy. J Clin Anesth. 2005;17:187-90.

15. Messenger DW, Murray HE, Dungey PE, Vlymen JV, Sivilotti ML. Subdissociativedose ketamine versus fentanyl for analgesia during propofol procedural sedation: a randomized clinical trial. Acad Emerg Med. 2008;15:1-10.

16. Andolfatto GM, Riyad M, Abu-Laban M, Zed JP, Staniforth SM. Ketaminepropofol combination (ketofol) versus propofol alone for emergency department procedural sedation and analgesia:a randomized double-blind trial. Ann Emerg Med. 2012;59(6):504-12. 